\title{
STRUCTURAL CAPITAL VALUE ADDITION TO TIMBER AND RELATED INDUSTRIES VALUE CHAIN
}

\author{
O VALOR ACRESCENTADO PELO CAPITAL \\ ESTRUTURAL À CADEIA DE VALOR DA \\ MADEIRA E INDÚSTRIAS RELACIONADAS
}

Carlos-Maria Fernandez Jardón ${ }^{1}$ Amandio F. C. da Silva²

1 University of Vigo, Facultad de Ciencias Económicas y Empresariales, Departamento de Economía Aplicada, Vigo, Spain.

2 Universidade de Aveiro, Faculty at the Instituto Superior de Contabilidade e Administração (ISCA), Aveiro, Portugal.

\begin{abstract}
Purpose - Structural capital is a component of intellectual capital. Its measurement is essential to obtain the real value of intellectual capital and its influence on profitability. This article aims at understanding the impact of structural capital on timber and related industries value chain of Galicia (Spain).

Design/methodology/approach - The wood sector chain was divided into three major sectors: extraction, conversion and finished products. Using a panel data model, we measured the value addition created by structural capital for the period of 2002-2018.

Findings - Structural capital brings value addition to extraction and finished products sectors of the value chain. The sector and the territory limit value generation and efficiency of structural capital.

Research limitations/implications - We took an extensive data set ranging from 2002 to 2018 of a relatively small region (Galicia). The findings could change if the area is expanded and/or other regions covered.

Practical implications - For business managers and consultants, this study suggests the need for benchmarking and cooperation practices between companies to increase efficiency. Entrepreneurs must concentrate more on intellectual capital in order to better performance.

Social implications - Local governments and social entities should acknowledge the importance of intellectual capital while implementing regulations and specific actions to improve SMEs profitability.

Originality/value - This paper measures the impact of structural capital on the timber value chain. SC is taken as an independent variable, unlike previous measurement models, where it was a remainder value after deducting HC from IC.

Keywords - Structural capital, intellectual capital, value chain, value addition.
\end{abstract}




\section{RESUMO}

Objetivos - O capital estrutural é um componente do capital intelectual. A sua medição é essencial para obter o valor real do capital intelectual e a sua influência nos lucros. Este artigo mede o impacto do capital estrutural na cadeia de valor madeireira da Galícia (Espanha).

Desígnio/metodologia/abordagem - Dividimos a cadeia madeireira em três grandes setores: extração, conversão e produtos finais. Usando um modelo de painel de dados, medimos o valor acrescentado criado pelo capital estrutural para 2002-2018.

Resultados - O capital estrutural gera valor acrescentado nos setores de extração e produtos finais. O sector e o território limitam a criação de valor e eficiência do capital estrutural.

Limitações/implicações de pesquisa - Usamos uma base de dados extensiva 2002-2018 de uma região relativamente pequena (Galícia). Os resultados poderiam diferir se a área de estudo fosse expandida e/ou outras regiões estudadas.

Implicações práticas - Para empresários e consultores, este estudo sugere a importância das práticas de criar objetivos e cooperação entre empresas para aumentar a eficiência. Os empreendedores devem concentrar-se mais no capital intelectual para melhorar o desempenho.

Implicações sociais - Governos locais e entidades sociais devem reconhecer a importância do capital intelectual ao implementar regulações e ações específicas visando melhorias nos lucros das PMEs.

Originalidade/valor - Este artigo mede o impacto do capital estrutural na cadeia de valor madeireira. O capital estrutural é considerado como uma variável independente, diferente dos modelos de medição anteriores, onde era apenas um valor residual da diferença entre capital humano e capital intelectual.

Palavras-chave - Capital estrutural, capital intelectual, cadeia de valor, adição de valor.

\section{INTRODUCTION}

Forestry has a long history in Europe since the middle ages, over-exploitation becoming common with the growth of population (Angelstam et al., 2005) and in the last decades of the $20^{\text {th }}$ century, attempts have been made to establish a regulatory framework for forestry management and protection through inter-governmental agreements (Sayer \& Maginnis, 2015). Forestry still complements traditional agriculture production, generating income in less dense zones while giving jobs to people (Mourão \& Martinho, 2016) and while the paper and pulp industries are dominated by a small number of multinationals, forests are mostly owned by local people trying to improve their livelihood (Sayer \& Maginnis, 2015). It is still considered an important economic sector making an important economic effect in the rural areas of many EU countries (Slee, 2006).

In a simplified way, structural capital consists of the stock of knowledge that stays in the organization at the end of the day, when the employees go home, so it is the tacit and explicit knowledge that remains in the organization after the employees leave (Kaya, Sahin \& Gurson, 2010).

Previous literature suggest that structural capital does add value to the organization, per se. (Petty \& Guthrie, 2000; Edvinsson, 1997), but the effect about the value generation of structural capital is discussed. For example, Hejazi, Ghanbari \& Alipour (2016) in Iranian companies listed in the Tehran stock exchange.

The structural capital is closely related to the culture and particularly with the culture of the territory. This makes territorial factors possibly change the impact of structural capital. This paper tries to analyze how structural capital generates value in the value chain of products derived from wood in a European region (Galicia).

Though there have been various studies in the areas of knowledge management and intellectual capital, very few have been specifically made on the Spain (Galicia) region on the timber and related industries that are dominated by SMEs with very few large, publicly traded companies. Some studies on the timber industry of Argentina and Latin America were found (Martos, F-Jar- 
dón \& Figueroa, 2008; F-Jardón \& Martos, 2014; F-Jardón \& Silva, 2017) but none on the Spanish area, as far as intellectual capital is concerned. The studies on Spain were mainly related to forest management (Carvalho-Ribeiro \& Lovett, 2011) or ownership issues (Marey-Perez, Diaz-Varela \& Calvo-Gonzalez, 2014). There are also works that analyze this impact in Latin American countries. However, the cultural characteristics of Galicia that combine Latin American culture with European culture possibly produce different results than previous studies. Furthermore, this is the first time that a study has been carried out on the effect of structural capital in the different links of the value chain. In this way, two fundamental questions can be answered: first, Does structural capital generate value in the different development processes of the wood value chain? Second, in which link is the most value generated?

This paper aims at detecting which is the sector among timber and related industries that generates the most value in Galicia (Spain); analyze whether structural capital generates value in all sectors; and determine in which sector specifically structural capital generates more value. Though there have been various studies in the areas of knowledge management and intellectual capital, very few have been specifically made on Spain (Galicia) region on the wood sector and related industries that are dominated by SMEs with very few large, publicly traded companies.

The article contributes in different theoretical and methodological aspects: first, it contributes new knowledge about the effect of structural capital on the generation of value in timber companies. Second, it shows in which link in the wood value chain generates economic value from structural capital. Finally, the paper suggests a new method of evolution of structural capital based on financial data.

The rest of paper continues with an analysis of structural capital in the wood sector, value generation, followed by the methodology and empirical analysis. It ends up with the discussion and conclusions.

\section{THEORETICAL BACKGROUND}

\subsection{FORESTRY SECTOR OF GALICIA (SPAIN)}

Forestry has a long history in Europe, dating from the middle ages but with the growth of population, destructive over-exploitation of forests became common, as is the present case in many tropical developing countries. Recent decades have seen a proliferation of innovative management in forestry in Europe (Angelstam et al., 2005).

The last decades of the $20^{\text {th }}$ century saw unprecedented changes in forestry, as the sustainability of tropical forests became critical. The paper and pulp industry started being dominated by a small number of MNCs, while the forests continued to be owned by local people trying to improve their livelihood. Attempts have been made to establish a global regulatory framework for forestry management and protection through intergovernmental agreements (Sayer \& Maginnis, 2015).]

Forestry is (still) an important economic sector that makes substantial contributions in the rural socioeconomic context and influences environmental conditions. Indeed, forestry can complement traditional agricultural production, generating more income in less dense zones and creating employment (Mourão \& Martinho, 2016). Forestry is being increasingly recognized as a critical activity for retaining viable livelihoods within rural areas of many EU countries (Slee, 2006). The agroforestry sector occupies a large part of the EU territory, giving a very important role to agriculture and forestry on the conservation of EU environmental resources (Martins, Xavier \& Fragoso, 2014). 
Galicia is a province in northwestern Spain characterized by a high relative percentage of its total forest area, which represents over $60 \%$ of its surface area and accounts for $11 \%$ of the total forest area of Spain (Marey-Perez, Diaz-Varela \& Calvo-Gonzalez, 2014), the stock of timber being more than 133 million $\mathrm{m}^{3}$, accounting for $19 \%$ of the total Spanish timber reserve and representing nearly half of the Spanish production of timber, with $98 \%$ of the forests being privately owned and the remaining $2 \%$ owned by the public sector (Caballero, 2015).

\subsection{INTELLECTUAL CAPITAL, HUMAN CAPITAL AND STRUCTURAL CAPITAL}

One of the earliest definitions of intellectual capital was given by Stewart (1991) where he defined it as sum of patents, processes, management skills, technologies, information on clients and suppliers and overall experience that gives an edge to the company in the marketplace.

Intellectual capital comprises those intangible assets that may generate future benefits for the organization and that create key competitive advantages for the business and are invisible, not easily quantifiable or acquirable or valued monetarily (Lopes \& Martins, 2006).

Many researchers in the area agree that intellectual capital should be classified into three types of capital: human capital, structural capital and customer/relational capital (Saint Onge, 1996; Sveiby, 1998; Bontis, 1998; Bozbura, 2004). Customer/relational capital was separated from the original classification of two types of capital (human capital and structural capital given by Edvinsson \& Malone, 1996), namely from the structural capital and was defined as the summation of relationships, interactions, and intimacy of an organization with its customers (Stewart, 1994).

Human capital is defined as the stock of skills, knowledge, expertises of employees which further play an integral role in increasing the productivity of the organization. Every organization invests part of its money and resources to train employees. Employees in turn work hard, upgrade their existing knowledge and contribute in their own way to increase the productivity of their organization (Kucharčiková, Tokarčiková \& Blašková, 2015).

Human capital is the sum of all the capabilities of the individuals responsible for providing customer solutions (Stewart, 1998). It consists of all the attributes related to human beings in the organization, namely the exposure, experience, skills, innovative and creative capabilities and contains all the intangible information and knowledge in the human minds of the employees of the organization (Bontis, Crossan \& Hulland, 2002).

According to the IFAC (1998), human capital is composed of:

- Know-how

- Education

- Vocational qualification

- Work-related knowledge

- Occupational assessments

- Psychometric assessments

- Work-related competencies

- Entrepreneurship, innovation, reactive abilities, etc.

Structural capital, also known as organizational capital is that capital existent in the organization in the form of the stock of patents, trademarks, hardware, software, databases, organizational culture and organizational capabilities, which cannot be taken away when employees leave (Edvinsson \& Malone, 1996; Roos \& Roos, 1997).

Structural capital is defined as the supporting infrastructure of human capital (Bontis, 1999). It is the knowledge that stays in the firm when employees go home for the night (Roos et al., 1998). 
Intellectual capital by itself is of little value without the leveraging effect of the firm's structural capital (Stewart, 1997). Structural capital is the embodiment, empowerment, and supportive infrastructure of human capital that provides the environment that encourages individuals to invest their human capital to create and leverage its knowledge (Cohen \& Kaimenakis, 2007). It also includes the organizational capacity, including the physical systems used to transmit and store the intellectual material of the organization (Edvinsson \& Malone, 1996).

According to the IFAC (1998), structural (organizational) capital is composed of:

- Patents

- Copyrights

- Designs

- Trademarks

- Trade or company secrets

- Service marks, etc.

- Management philosophy

- Corporate culture

- Management processes

- Information systems

- Networking systems

- Financial relations

As per Kavida \& Sivakoumar (2009), structural capital is everything that supports the employees of the company, in other words, the human capital. Structural capital contains elements like organization image, information systems, and databases, in addition to conventional elements, such as company building, processes, patents and brands. Structural capital is the physical and organizational structure, property of the enterprise, which supports human capital and facilitates knowledge transfer. It consists of internal processes capital and research, development and innovation capital. Internal processes capital is related to quality of processes, products and services that gives the company its competitive advantages. $R \& D$ capital includes investments that are made in developing new products, new technologies (Ciprian et al., 2012).

\subsection{DO INTELLECTUAL CAPITAL AND ITS COMPONENTS ADD VALUE ${ }^{1} ?$}

Intellectual capital is the platform of any business model and its value creation and without it, there is no value creation (Nielsen \& Nielsen, 2019). It also generates innovation in corporations (Nejjari \& Aamoum, 2020).

Intellectual capital, through its three components, human capital, structural capital and relational capital, adds value to the firm. While the majority of studies was concentrated on human capital efficiency, several authors admitted the importance of structural capital and relational capital as contributors to value addition to the firm. Midiantari \& Agustia (2020) argue that intellectual capital proxied by human capital, structural capital, customer capital and corporate reputation have a significant effect on firm value. Additionally, structural capital has a significant effect on corporate reputation.

Previous literature suggest that structural capital does add value to the organization, per se. A study based on the first 122 Fortune Global 500 companies published by their CEOs to the

1 Our discussion here is limited to intellectual capital and structural capital. 
shareholders between 2008 and 2012 found out that those that have a positive evolution in the ranking focused significantly on structural capital and those that had a negative evolution in the ranking focused more on the relational capital (Albertini, 2016).

In a longitudinal study of Austrian companies, Leitner (2011) found out that firms that have strength in both human and structural capital have a higher likelihood of being highly innovative.

As structural capital, to a large extent, is invisible in traditional accounting, the important question of value extraction does not gain the same immediate attention (Edvinsson, 1997). It is fundamental to successful knowledge management and a key asset to organizational knowledge management efforts. A higher level of structural capital should facilitate knowledge management. Moreover, structural capital and cognitive capital ${ }^{2}$ are positively associated with organizational emphasis on knowledge management.

Several studies around the world have given mixed conclusions between the structural capital efficiency and value addition to the firm (see table 1). Some of the most recent ones did not find any positive correlation between structural capital and value creation for the firm, as in the case of Hejazi, Ghanbari \& Alipour (2016) in Iranian companies listed in the Tehran stock exchange and Wu, Lin \& Hsu (2007) in Taiwan, found a significant positive relationship between structural capital and financial and innovative performance. 
Table 1: Structural Capital Measurement Approaches

\begin{tabular}{|c|c|c|c|}
\hline Dependent Variable & SC Measure & $\begin{array}{l}\text { Effect } \\
\text { Sign }\end{array}$ & Reference \\
\hline ROA & $\begin{array}{l}\text { Net sales/R\&D ex- } \\
\text { penses }\end{array}$ & NS & \multirow[t]{6}{*}{ (Vishnu \& Gupta, 2014) } \\
\hline $\begin{array}{l}\text { ROS (EBITDA divided } \\
\text { by net sales) }\end{array}$ & Net sales/R\&D expenses & NS & \\
\hline ROA & VA/R\&D expenses & $\mathrm{P}+$ & \\
\hline $\begin{array}{l}\text { ROS (EBITDA divided } \\
\text { by net sales) }\end{array}$ & VA/R\&D expenses & NS & \\
\hline ROA & R\&D expenses/ Net sales & N- & \\
\hline $\begin{array}{l}\text { ROS (EBITDA divided } \\
\text { by net sales) }\end{array}$ & R\&D expenses/ net sales & NS & \\
\hline ROE & VAIC & NS & \multirow[t]{2}{*}{ (Xu \& Wang, 2018) } \\
\hline ROA & VAIC & NS & \\
\hline ROA & VAIC & NS & (Ahangar, 2011) \\
\hline Growth of Sales & VAIC & NS & \\
\hline Employee Productivity & VAIC & NS & \\
\hline ROA & VAIC & $\mathrm{P}+$ & (Dadashinasab \& Sofian, 2014) \\
\hline Qualitative & Questionnaire Survey & $\mathrm{P}+$ & (F-Jardón \& Silva, 2017) \\
\hline Qualitative & Questionnaire Survey & $\mathrm{P}+$ & (Costa, F-Jardón \& Dorrego, 2014) \\
\hline Qualitative & Questionnaire Survey & NS & (F-Jardón, Costa \& Dorrego, 2014) \\
\hline ROA & VAIC and EVA & NS & (lazzolino, Laise \& Migliano, 2014) \\
\hline Qualitative & Questionnaire Survey & $\mathrm{P}+$ & (Hsu \& Wang, 2010) \\
\hline Qualitative & Questionnaire Survey & $\mathrm{P}+$ & (Loureiro \& Dorrego, 2012) \\
\hline Qualitative & Questionnaire Survey & $\mathrm{P}+$ & (Hsu \& Fang, 2009) \\
\hline ROA & VAIC & $\mathrm{P}+$ & (Sherif \& Elsayed, 2016) \\
\hline Qualitative & Questionnaire Survey & $\mathrm{P}+$ & (Shih, Chen \& Morrison, 2010) \\
\hline ROA & Custom made models & $\mathrm{P}+$ & (Sydler, Hefliger \& Pruska, 2014) \\
\hline ROA & Custom made models & $\mathrm{P}+$ & (Urban \& Joubert, 2017) \\
\hline ROA & ICER & $\mathrm{P}+$ & (Urbanek, 2016) \\
\hline Qualitative & Questionnaire Survey & $\mathrm{P}+$ & (Chen, Zhao \& Wang, 2015) \\
\hline
\end{tabular}

Source: Own Compilation

NS: Not Significant; P+: Positive; N-: Negative

A thorough understanding of and the efficient management of structural capital (particularly the innovation and process capital components), provides an organization with valuable opportunities and tools for achieving sustainable competitiveness and prolonged first-mover advantage in today's dynamic and competitive marketplace (Zyl, 2005).

Structural capital is an important resource (asset) both at the micro (company) and macro (economic) levels. Structural capital like other components of intellectual capital brings value to the organization, and competitors cannot easily imitate it. Consequently, it confers a sustained competitive advantage to the owners. Structural capital allows tangible and intangible resources, such as machines, patents, brands, and human capital, to be productive. Managing this capital is of great importance for companies to improve their productivity and long-term competitive advantage. Sim- 
ilarly, its management allows limiting the downside risks, for example, associated with disruptive technologies. Companies also need a comprehensive measure of structural capital to inform investors and other stakeholders to understand the company's value factors. Finally, executives and board members must make investments in structural capital to improve their productive operations and to adapt to new ways of doing business (Lev et al., 2016).

Pedro et al. (2018) suggest that the fourth stage of intellectual capital is aimed at measuring regional and national intellectual capital. This work is oriented at connecting the measures of the organizational structural capital with the regional one, making use of the global value chains (Giuliani et al. 2005). This concept indicates that part of the value of the global production chain is due to the region (Contreras et al. 2012). In this sense, this paper makes use of the forest value chain to evaluate the structural capital of Galicia.

Forest-based industries have an unquestionable importance in the context of the economy, due to their value addition to the GDP, exports, job creation via the great number of economic agents involved in the production, conversion and marketing of the products and by its great relevance in the settling of the population in the least developed regions of the country (Sarmento \& Dores, 2013).

In a study in Malaysia, Yusliza et al. (2020) examined the relationship between green intellectual capital ${ }^{3}$ and sustainability, concluding that it, through its three components (in this case green human capital, green structural capital and green relational capital) positively impacted economic, environmental, and social performance, as long as companies adopt cleaner production capabilities. In a somewhat similar study, Sudibyo \& Sutanto (2020) discovered that corporate social responsibility has a positive effect on green human capital, green structural capital, and green relationship capital, whereas environmental consciousness has a positive effect on green human capital and green structural capital, but not on the dimension of green relationship capital.

Masaro et al. (2018) also found out that intellectual capital and sustainability influence each other in answering a plurality of demands and logics. Similarly, in a study in Pakistan's listed textile firms, Ahmad, Mohammd \& Nordin (2019) concluded that structural capital had a positive significant effect on business performance and its dimensions can be considered as significant predictors of business performance.

Pietrobelli \& Rabellotti (2014) highlight the importance of the natural resource-based clusters to participate in a global value chain that offers business promising opportunities, the adoption of sanitary standards and environmental regulations, and quality inspections and controls. Consequently, the use of a value chain to analyze the evolution of timber industry, allows to detect the link that is most important in the value generation by structural capital. The second aim is to analyze how the timber industry generates value from structural capital in the different links of the value chain. In order to evaluate the value generation this paper proposes a new method using financial data to evaluate this effect.

According to Maharani \& Fuad (2020), human capital can have a negative and insignificant effect on profitability unless proper human resource management coupled with improvements in the efficiency in the company is implemented. Increasing human capital without the proper motivation will simply increase costs. However, structural capital has a significant positive effect on profitability as it has an impact on efficient production processes and is able to reduce unwanted production costs, and should also be properly managed.

3 Green intellectual capital is the integration of intellectual capital and environmental concerns at organizational or personal level (Chen, 2008). 


\subsection{THE FOREST-BASED VALUE-CHAIN}

A value-chain is an alliance of consecutive collaborating enterprises (sometimes also referred to as "vertically collaborating") to achieve a more rewarding position on the market. Consecutive or sequential alignment means that companies are connected from one end of the primary production process (e.g. forestry), through processing, and possibly into the final marketing stages where customers purchase retail or consumer products (Teischinger, 2009).

Kaplinsky (2000) defined a value chain as the full range of activities which are required to bring a product or service from conception through the intermediary phases of production (involving a combination of physical transformation and the input of various producer services), delivery to final consumers and final disposal after use.

The EU-commission "Enterprise and Industry" that comprises of 35 different sectors of which one of them is the "forest-based industries sector" paper manufacturing, paper \& board converting and printing. Wood furniture is part of a separate furniture sector ${ }^{5}$, but wood-based furniture contributes to the forest-based industry sector. This makes a precise documentation (statistics) of the forest-based sectors and its subsectors and value chains sometimes very difficult to analyze (Teischinger, 2009).

The production and marketing of forest products is an important source of rural employment and income, with benefits extending beyond the forest area, as the products move from production to end-use through different stages of processing and marketing (Poschen, Sievers \& Abtew, 2013).

Small forest-based businesses are usually organized as subsistence small businesses (SSBs) (F-Jardón \& Silva, 2017), and are very conditioned by the local culture of the region (F-Jardón \& Martinez-Cobas, 2020). If the farmers would acquire a greater understanding of the market dynamics, they could better target the sale of their forest products to specific market segments and make forestry a more profitable enterprise, as further downstream the position of the stakeholder in the value chain, the greater the monetary value added to the timber and subsequent products (Irawanti et al., 2017).

Leadership in SSBs is limited since entrepreneurs tend to have little training and business knowledge is usually based on experience and not on strategic approach (F-Jardón \& Cobas, 2019), or in other words, their human capital is poor. However, the study of Dal Mas (2019) proves that intellectual capital through its components influences sustainability of businesses.

In this paper, we will try to understand the contribution of structural capital to the value chain and to value addition.

In a study of basic metal and forest industries using bulk production processes, (Koota \& Takala, 1998) found out that the performance measurement system depended on six factors, namely, importance of internal customers to performance, formulation of performance in own activities, effect of distribution logistics performance on the overall profitability, level of service realized in own operations, and development of the highly emphasized innovativeness in the distribution logistics.

\subsection{STRUCTURAL CAPITAL IN THE VALUE CHAIN}

In this study, we will attempt to measure the importance of structural capital as a value creator for the wood sector of Galicia. We divided the timber and related industries value chain

4 http://ec.europa.eu/interprise/forest_based/index_en.html

5 http://ec.europa.eu/interprise/furniture/index_en.html 
into three sectors: extraction, conversion and finished products, in order to better analyze the forest-based value chain.

The division into three sectors was made in order to aggregate the myriad activities under the wood sector. While extraction has to do with logging, forestry activities and other related industries, conversion is the next sector which converts the wood products either into raw materials or products of end-use to the customers. Finally, finished products comprises of all the products and derivates made for the final consumer, like paper, wooden furniture, and others. By making such a segregation, it is easier to understand the value addition of structural capital to sectors with different characteristics and different end-users.

The extraction sector in our study comprises of activities of forestry and logging, cork extraction, silviculture, and other related industries.

In Galicia (Spain), the property rights of Galician communal forests are private but collective with the passing of the Galician Act of Communal Forests of 1989 (Caballero, 2015). Nevertheless, the forestry (extraction) sector is still dominated by small and medium enterprises, and even by subsistence small businesses (F-Jardón \& Silva, 2017). In the case of SMEs, higher business performance is related to higher levels of intellectual capital and innovation culture (Dabić et al.,2019).

The competitiveness of companies in these activities is essentially based on their ability to select the raw material and the methodology for obtaining it. For both elements, the traditional knowledge that the producers have of the forest and natural resources is essential, as well as the way of organizing them, normally based on traditional techniques (Martos, F-Jardón \& Figueroa, 2008). All these elements are part of structural capital. Consequently, we propose the following hypotheses in order to understand the level of value creation by structural capital in Galicia (Spain):

\section{H1: Structural capital creates value in the extraction sector}

The conversion sector in Galicia (Spain) comprises of construction carpentry, pulp and timber mills, which is mainly dominated by large companies, some of them, not listed on the stock exchanges. It was necessary to segregate the conversion sector from the other two sectors as it has a mixture of small and medium enterprises with large companies mainly operating in the pulp manufacture. Again, given the diversity of sizes between both countries under study, it was not possible to combine them into one.

These companies compete essentially in the way of presenting the transformed work, in the ability to attract clients, both companies and consumers, which is based on their relationships essentially in the territory. Consequently, their knowledge of local customers and their know-how based on cultural tradition will be essential for their competitiveness (Coyte, Ricceri \& Guthrie, 2012). Both elements that are included within its structural capital. Consequently, we propose the following hypotheses in order to understand the level of value creation by structural capital in Galicia (Spain):

\section{H2: Structural capital creates value in the conversion sector}

The finished products include every industry that is dependent on wood and that is not part of extraction or conversion, namely paper and its articles, cardboard, wood and its articles, wooden furniture. The sector is characterized by the existence of large multinational companies as well as small players in the unorganized sector, better fitted under the small and medium enterprises.

In the small and medium-sized companies that carry out these activities, it is essential that they know how to adapt the products to the needs of the client, which requires a knowledge of the local market that is fundamentally based on the traditions and culture of the territory (Gatto, 1999), 
elements included in the structural capital. Consequently, we propose the following hypotheses in order to understand the level of value creation by structural capital in Galicia (Spain):

\section{H3: Structural capital creates value in the finished products sector}

\section{METHODOLOGY}

\subsection{DATA}

Using the data from the SABI database for all the companies in the industries related to the wood and ancillary sector for the financial years 2002-2018, but only considering companies that had financial data for 2016-2018, the structural capital and its effect on value addition were calculated for every company that had positive values (where VA > SC), year wise. All outliers (5\%) were eliminated to get lesser skewed results. The data was divided country-wise into three main sectors: extraction, conversion and finished products, to facilitate and segregate the interpretation.

Table 2 shows descriptive statistics of the variables used in the analysis In it, it can be seen that the added value is generated essentially in the finished products, although they are also the companies owning the greatest assets by value, on average.

Table 2: Descriptive statistics of value added, total assets and structural capital

\begin{tabular}{|c|c|c|c|c|c|c|c|c|c|c|}
\hline & & \multicolumn{3}{|c|}{ Extraction } & \multicolumn{3}{|c|}{ Conversion } & \multicolumn{3}{|c|}{ Finished products } \\
\hline & & $\mathbf{N}$ & Mean & Std.Dev & $\mathbf{N}$ & Mean & Std.Dev & $\mathbf{N}$ & Mean & Std.Dev \\
\hline Galicia & change in IA & 262 & 0.85 & 22.05 & 693 & 1.80 & 122.58 & 784 & 3.17 & 189.09 \\
\hline & total assets & 262 & 417.10 & 2422.15 & 693 & 667.45 & 1858.89 & 784 & 6804.51 & 45254.88 \\
\hline & VA & 262 & 70.87 & 1291.68 & 693 & 154.83 & 906.41 & 784 & 3490.63 & 28361.36 \\
\hline
\end{tabular}

\subsection{MEASUREMENT MODEL}

Many methods have been associated with the measurement of other components of intellectual capital, which in part limits their scope. The most common is the VAIC method of Pulic (2000) that measures structural capital as a remainder, that is, the part of added value not generated by human capital. Other authors estimate it from the company's operating expenses.

Another well-known model of measuring intellectual capital components are the Calculated Intangible Value (CIV), that is a super-profits method to value a company, where intellectual capital is the difference between maintainable profit and expected return on the tangible assets employed (Rawal \& Mahini, 2014). This model does not work if the average ROA calculated is below the industry average, and it is not possible to segregate intellectual capital from goodwill.

In 1999, Lev proposed a model, the Knowledge Capital Earnings (KCE ${ }^{\mathrm{TM}}$ ) that calculates the intellectual capital based on the normalized earnings of the last three years and the earnings for the next three years based on forecasts. The main limitation of the model being that it does not segregate the components of intellectual capital (Ujwary-Gil, 2012).

A lesser known model is Urbanek's (2016) Intellectual Capital Efficiency Ratio (ICER), that uses public listed companies' data to compare different companies. It is based on the difference of the market value and book value of the company in order to measure the intellectual capital. However, while it corrects the limitation of VAIC ${ }^{\mathrm{TM}}$ of considering structural capital as a residual value, it ignores totally relational capital. 


\subsection{OUR MODEL TO MEASURE STRUCTURAL CAPITAL}

This research uses the change of intangible assets as measure of investments in structural capital. Consequently, we have defined SC as the difference between the intangible assets between two consecutive years ( $t-t-1)$.

We used a modified ROA model to study the intellectual capital value addition in the timber and related sectors, brought about by structural capital.

This model measures all the three components of intellectual capital, namely human capital (considered as the control variable 1), structural capital, and relational capital (considered as the control variable 2 ).

The proposed model is:

$$
\frac{\mathrm{VA}}{\mathrm{TA}}=\beta_{0}+\beta_{1} \frac{\mathrm{HC}(\text { Control1) }}{\mathrm{TA}}+\beta_{2} \frac{\mathrm{SC}}{\mathrm{TA}}+\beta_{3} \frac{\mathrm{RC}(\text { Control2) }}{\mathrm{TA}}+\varepsilon
$$

With this model, it is aimed to answer the main question:

- Is the efficiency of structural capital significant in the timber and related industries, after removing the effect of the control variables?

\subsection{STATISTICAL METHODS}

This work uses a one-way dynamic panel data regression model with the software $R^{6}$ to estimate the effect of structural capital in each equation. Dynamic panel data was used due to the fact that we had a two-dimensional data series, comprised of a cross-sectional dimension of company data and a time-series dimension spanning from 2002-2018.

Based on the results, it is possible to estimate whether the hypotheses established are satisfied and their significance. In addition, we have conducted a Kruskal-Wallis test at a confidence level of $95 \%$ to compare the differences in all the three sectors for each country.

\section{EMPIRICAL RESULTS}

Based on the proposed model, we calculated the efficiency of structural capital in generating value in each of the previously established sectors of Galicia.

Table 3 shows the results of estimation using the model prescribed above, for the structural capital for each of the three sectors: extraction, conversion and finished products, in each country. 
Table 3A: regression of structural capital on value added

\begin{tabular}{|c|c|c|c|c|c|}
\hline & & \multicolumn{3}{|c|}{ effect of structural capital on value added } \\
\hline \multirow{2}{*}{ Region } & Sector & Estimate & Std. Error & t-value & $\operatorname{Pr}(>|\mathrm{t}|)$ \\
\hline \multirow{3}{*}{ Galicia (Spain) } & Extraction & 0.2692 & 0.1050 & 2.5640 & $0.0104^{*}$ \\
\cline { 2 - 6 } & conversion & 0.1309 & 0.1663 & 0.7871 & 0.4313 \\
\cline { 2 - 6 } & Finished products & 0.8846 & 0.4087 & 2.1646 & $0.0305^{*}$ \\
\hline
\end{tabular}

Table 3B: regression of human capital on value added (control variable 1)

\begin{tabular}{|c|c|c|c|c|c|}
\hline & & \multicolumn{3}{|c|}{ effect of structural capital on value added } \\
\hline \multirow{2}{*}{ Region } & sector & Estimate & Std. Error & t-value & $\operatorname{Pr}(>|\mathrm{t}|)$ \\
\hline \multirow{3}{*}{ Galicia (Spain) } & Extraction & 0.3499 & 0.0169 & 20.6498 & $<2 \mathrm{e}-16^{* * *}$ \\
\cline { 2 - 6 } & conversion & 0.1127 & 0.0093 & 12.0212 & $<2.2 \mathrm{e}-16^{* * *}$ \\
\cline { 2 - 6 } & Finished products & 0.01025 & 0.0062 & 1.6556 & 0.09797 \\
\hline
\end{tabular}

Table 3C: regression of relational capital on value added (control variable 2)

\begin{tabular}{|c|c|c|c|c|c|}
\hline & & \multicolumn{4}{|c|}{ effect of structural capital on value added } \\
\hline \multirow{2}{*}{ Region } & sector & Estimate & Std. Error & t-value & $\operatorname{Pr}(>|\mathrm{t}|)$ \\
\hline \multirow{3}{*}{ Galicia (Spain) } & Extraction & -0.1945 & 0.1445 & -1.3458 & 0.1785 \\
\cline { 2 - 6 } & conversion & 0.8635 & 0.1796 & 4.8065 & $1.586 \mathrm{e}-06^{* * *}$ \\
\cline { 2 - 6 } & Finished products & 1.7685 & 0.1421 & 12.4387 & $<2 \mathrm{e}-16^{* * *}$ \\
\hline
\end{tabular}

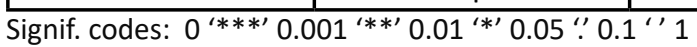

In the case of the extraction sector of Galicia, the results indicate that structural capital creates value in the extraction sector with a significance code of 0.01 , implying that structural capital creates value directly to the sector.

Similarly, the results show structural capital creates value in the conversion sector is not satisfied, implying that structural capital does not directly affect value creation to the sector.

Finally, structural capital creates value in the finished products sector is satisfied with significance code of 0.01 , implying that structural capital creates value directly to the sector.

\subsection{VALUE ADDITION OF STRUCTURAL CAPITAL}

Once the sector of the wood value chain where the impact of structural capital occurs is found out, we will study in which sector the greatest value is generated and the efficiency level of value generation using structural capital.

Table 4: T-statistics comparative among sectors in Galicia

\begin{tabular}{|l|c|c|c|c|}
\hline \multicolumn{2}{|c|}{ t-stat } & \multicolumn{2}{c|}{ Galicia (Spain) } & \\
\hline & & Extraction & conversion & Finished products \\
\hline \multicolumn{2}{|c|}{ Galicia (Spain) } & & & \\
\hline & conversion & 0.99 & & \\
\hline & Finished products & $-2.06^{*}$ & $-2.41^{* *}$ & \\
\hline
\end{tabular}


Table 4 collects the t-statistics comparing the two-year effects to each sector within the value chain. The table shows that the effect of structural capital in the extraction sector in Galicia is significantly less than the finished products sector in Galicia. The effect on the conversion sector is significantly less than that of finished products.

\section{DISCUSSION}

This work analyzes the generation of value from structural capital in the value chain of the wood companies of Galicia. The results are different according to the sector and the region studied.

Table 5 summarizes the effects of structural capital on value added in each sector. The results show that only a significant effect of structural capital appears in the extraction and finished products sectors in Galicia.

Table 5: Results for both regions per sector

\begin{tabular}{|c|c|c|c|}
\hline & \multicolumn{2}{|c|}{ Does structural capital create value? } \\
\hline & Extraction sector & Conversion sector & $\begin{array}{c}\text { Finished Products } \\
\text { Sector }\end{array}$ \\
\hline $\begin{array}{c}\text { GALICIA } \\
\text { (SPAIN) }\end{array}$ & yes & no & yes \\
\hline
\end{tabular}

Structural capital, per se, does not create value in timber and related industries of Galicia, except in the case of the extraction sector and finished products sector. The timber and related industries use mostly manpower and less automatization, and this exception could be due to the high mechanization of the extraction and finished products sector of Galicia.

Structural capital is less obvious and more specialized than other components of intellectual capital (Moon \& Kym, 2006). Value creation is mostly done due to the interaction between the components of intellectual capital, namely human capital, structural capital and relational capital (Hezaji, Ghanbari \& Alipour, 2016).

While most studies consider human capital as the main factor that influences performance (Astebro \& Bernhardt, 2005), structural capital and relational capital are major factors in transforming the knowledge embedded in individuals and organizations into value (Schiuma \& Lerro, 2008). In other words, while structural capital does not create value directly in this study, it is dependent on human capital and may create value indirectly. Similarly, in this study, the value creation by intellectual capital could be caused by structural capital indirectly through the influence of human capital or relational capital.

The findings confirm the results obtained in the previous literature. The typology of the companies coincides with those of the extraction sector of Galicia, companies closely linked to the territory (F-Jardón \& Tañski, 2018), which facilitates the use of organization to generate value.

Similar results, with different methodology, based in VAIC or ICER and using ROA as dependent variable, obtained (Sherif \& Elsayed, 2016) in the insurance sector in Egypt, (Urbanek, 2016) with Polish food companies and (Dadashinasab \& Sofian, 2014) with Malaysian companies (technology sector, consumer products sector, trading and service sector, and industrial products). Possibly, finished products companies in Galicia have similar characteristics. 
The work presents a novel structure dealing with the structural capital value generation capacity in the global value chain scheme (Giuliani et al. 2005). The results indicate that in the value chain of wood in Galicia, the main value generating sector is extraction.

The results obtained by a similar study in other regions of the world or in other economic sectors may be quite different, as the typical characteristics of the region can affect the performance of intellectual capital and its components.

The different behaviors of the sectors and the regions suggest the importance of the context (Martín-de Castro, 2014), both for the generation of value and for the amount of structural capital and for the efficiency in the use of it, suggesting the need for more in-depth studies to detect the factors that conditions that behavior.

The paper suggests a new model to evaluate the efficiency of structural capital. The advantages of this suggested model, as compared to the previous models, are:

- The model can be used for both listed as well as unlisted companies and SMEs, while models such as VAIC ${ }^{\text {TM }}$ can be used only for listed companies.

- It can calculate the value addition considering each of the components of intellectual capital separately, and thus surpassing the limitation of using a single numerator to calculate the efficiency of each component. In this model, structural capital is segregated as compared to KCE ${ }^{\mathrm{TM}}$ does not segregate the components of intellectual capital.

- Value added is considered as the sum of the intellectual capital of last year and the efficiency of each component in the current year.

- It does not require the market values, averages or listed prices in order to calculate the intellectual capital efficiency. Most other models require market values and averages or listed prices to reach the value of intellectual capital and structural capital.

- It enables comparison between companies and industries.

\section{MANAGERIAL AND SOCIAL IMPLICATIONS}

The results suggest a series of ideas on the actions of managers, consultants and politicians to improve the management of the companies in the wood and related sectors.

First, the fact that structural capital does not always have an effect on the generation of value suggests that some of the sectors analyzed make use of structural capital to generate value, while others do not. Companies should analyze the factors that limit the use of structural capital (Lev et al., 2016).

The differences in the generation of value between the different sectors and regions analyzed suggest actions that can be taken advantage of for their specific characteristics to improve the generation of value. For example, the sectoral differences in the same region suggest internal problems in the structure of the companies, while the regional differences suggest different political strategies. It also suggests cooperation strategies between different companies in different sectors to improve collective efficiency (Schmitz, 1995).

\section{CONCLUSIONS}

The objective of this paper was to analyze the way in which structural capital creates value within a global value chain structure, such as the case of wood in Galicia (Spain).

For this, the paper proposes an alternative way of evaluating structural capital within companies using financial data in such a way that its valuation is easy (Martín-de Castro, 2014). In addi- 
tion, the paper proposes a model to assess the efficiency of structural capital in a global value chain (Giuliani et al., 2005). The value chain of wood is divided in three sectors: extraction, conversion, and finished products that is indicated in the value generation process. Subsequently, this model is applied to each of the sectors of the wood value chain in the analyzed regions.

The results show that structural capital of companies in the wood chain only produces significant effects on added value in the case of extraction companies in Galicia and in finished products companies also in Galicia, while in the remaining sectors the effect was not significant. These differences in results are consistent with previous studies that indicate different effects according to the data, the methodology, and the way of measuring structural capital (Iazzolino, Laise \& Migliano, 2014; Urban \& Joubert, 2017).

Finally, the research tested in which of the sectors the effect of intellectual capital is more significant. The results indicate that the effect of structural capital in the extraction sector in Galicia is significant, as is the case with the finished products sector. In Galicia's finished products sector, the impact of structural capital is more significant than in the other sectors, indicating that it is in this sector that structural capital is best used. This result shows that the use of the organization is more efficient the more advanced the level of the value chain, since it needs greater specialization as well as greater technology for the development of its products (Landekić et al., 2015).

While this is an innovative study, using a new method to analyze the capital value addition of structural component of intellectual capital and its impact on the three main sectors of timber and related industries, it has its own limitations:

\section{LIMITATIONS AND FUTURE RESEARCH}

First, the study is limited to a small geographical region (Galicia in Spain) and does not cover the same industrial sector in other parts of Europe or the rest of the world. Thus, the results obtained by the study may not be considered as a representation of the entire timber and related industries sector or of other economic sectors. In addition, the study is limited to only one component of intellectual capital, namely structural capital, without considering directly the effect of human capital and relational capital on value addition. If all the three components of intellectual capital were considered together, the conclusions could be quite different. The research aims fundamentally at deepening and advancing the available knowledge and information about intellectual capital in a given industry (timber and its related products) by studying its three main sectors (extraction, conversion and final products) by proposing a new method of analysis of intellectual capital value addition to the sector.

Some of the SMEs may not disclose all the items of their balance sheet in detail, and this could hamper to some extent, the regression analysis in this study. Finally, while our study covered a vast number of years (2002-2018), the results could be different, if the number of years is increased or decreased. In addition, the number of variables used was limited to the three components of intellectual capital. If more related variables are added, the results can differ significantly.

It would be interesting to extend the study to other areas of the world, including both SMEs and other types of organizations or even using the same proposed model to study other sectors, making them thus, comparable on an equal basis. The study can also be modified by including more variables, like social capital ${ }^{7}$.

7 In this study, social capital was considered as a part of relational capital. 


\section{REFERENCES}

AHANGAR, R., (2011), The relationship between intellectual capital and financial performance: An empirical investigation in an Iranian company, African Journal of Business Management, 5(1), 88-95.

AHMAD, R.; MOHAMMAD, H.; NORDIN, S., (2019), Moderating effect of board characteristics in the relationship of structural capital and business performance: An evidence from Pakistan textile sector, Journal of Studies in Social Sciences and Humanities, vol. 5, no. 3, pp. 89-99.

ALBERTINI, E., (2016), An inductive typology of the interrelations between different components of intellectual capital, Management Decision, 54(4), 887-901.

ANGELSTAM, P.; KAPYLOVA, E.; KORN, H.; LAZDINIS, M.; SAYER, J.; TEPLYAKOV, V.; TORNBLOM, J., Changing forest values in Europe, in B.B., SAYER, J.; MAGINNIS, S.; LAURIE, M., (2005), (Ed.), Forests in landscapes: Ecosystem approaches to sustainability, The Earthscan Forestry Library, London, 59-74.

ASTEBRO, T.; BERNHARDT, I., (2005), The winner's curse of human capital, Small Business Economics, $24,63-78$

BONTIS, N., (1998), Intellectual capital: an exploratory study that develops measures and models, Management Decision, 36(2), 63-76.

BONTIS, N., (1999), Managing organizational knowledge by diagnosing intellectual capital, International Journal of Technology Management, 18(5-8), 433-462.

BONTIS, N.; CROSSAN, M.; HULLAND, J., (2002), Managing an organizational learning system by aligning stocks and flows, Journal of Management Studies, vol. 39, no. 4, pp. 437-469.

BOZBURA, F., (2004), Measurement and application of intellectual capital in Turkey, The Learning Organization, 11(4/5), 357-367.

CABALLERO, G., (2015), Community-based forest institutions in the Galician communal forests: A new institutional approach, Forest Policy and Economics, 50, 347-356.

CARVALHO-RIBEIRO, S.; LOVETT, A., (2011), Is an attractive forest also considered as well managed? Public preferences for forest cover and stand structure across a rural/urban gradient in northern Portugal, Forest Policy and Economics, 13(1), 46-54.

CHEN, J.; ZHAO, X.; WANG, Y., (2015), A new measurement of intellectual capital and its impact on innovation performance in an open innovation paradigm, International Journal of Technology Management, 67(1), 1-25.

CHEN, Y., (2008), The positive effect of green intellectual capital on competitive advantages of firms, Journal of Business Ethics, 77(3), 271-286.

CIPRIAN, G.; VALENTIN, R.; LUCIA, M.; MĂDĂLINA, G., (2012), Elaboration of accounting financial reporting on structural capital, Procedia - Social and Behavioral Sciences, 62, 706-710.

COHEN, S.; KAIMENAKIS, N., (2007), Intellectual capital and corporate performance in knowledgeintensive SMEs, The Learning Organization, 14(3), 241-262. 
CONTRERAS, O.; CARRILLO, J.; ALONSO, J., (2012), Local enterpreneurship within global value chains: A case study in the Mexican automotive industry, World Development, 40(5), 1013-1023.

COSTA, R.; F-JARDÓN, C.; DORREGO, P., (2014), Critical elements for product innovation at Portuguese innovative SMEs: An intellectual capital perspective, Knowledge Management Research \& Practice, 12(3), 322-338.

COYTE, R.; RICCERI, F.; GUTHRIE, J., (2012), The management of knowledge resources in SMEs: An Australian case study, Journal of Knowledge Management, 16(5), 789-807.

DABIĆ, M.; LAŽNJAK, J.; SMALLBONE, D.; ŠVARC, J., (2019), Intellectual capital, organizational climate, innovation culture, and SME performance: Evidence from Croatia, Journal of Small Business and Enterprise Development, 24(4), 522-544.

DADASHINASAB, M.; SOFIAN, S., (2014), The impact of intellectual capital on firm financial performance by moderating of dynamic capability, Asian Social Science, 10(17), 93-100.

DAL MAS, F., (2019), The relationship between intellectual capital and sustainability: An analysis of practitioner's thought, In: MATOS, F.; VAIRINHOS, V.; SELIG, P.; EDVINSSON, L., (eds), Intellectual Capital Management as a Driver of Sustainability, Springer, Cham.

EDVINSSON, L., (1997), Developing intellectual capital at Skandia, Long Range Planning, 30(3), 366-373.

EDVINSSON, L.; MALONE, N., (1996), Intellectual capital: Realizing your company's true value by finding its hidden brainpower, New York: Harper Business.

F-JARDÓN, C.; COSTA, R.; DORREGO, P., (2014), The impact of structural capital on product innovation performance: An empirical analysis, International Journal of Knowledge-Based Development, $5(1), 63-79$.

F-JARDÓN, C.; MARTOS, M., (2014), Intellectual capital and distinctive skills in SMEs of the timber industry in Argentina, Revista de Administração de Empresas, 54(6), 1-10.

F-JARDÓN, C.; TAÑSKI, N. C. (2018). Place-based competitiveness in subsistence small businesses. Journal of Entrepreneurship in Emerging Economies, 10(1), 23-41.

F-JARDÓN, C.; SILVA, A., (2017), Intellectual capital and environmental concern in subsistence small business, Management of Environmental Quality, 28(2), 214-230.

F-JARDÓN, C.; MARTINEZ-COBAS, X., (2019), Leadership and organizational culture in the sustainabiity of subsistence small businesses: An intellectual capital based view, Sustainability, 11, 3491, 1-16.

F-JARDÓN, C.; MARTINEZ-COBAS, X., (2020), Culture and competitiveness in small-scale LatinAmerican forestry-based enterprising communities, Journal of Enterprising Communities: People and Places in the Global Economy, 14(2), 161-181.

GATTO, F., (1999), Mercosur: Its challenges to small and medium-sized industrial enterprises in terms of competition, CEPAL Review, 68, August, 61-77.

GIULIANI, E.; PETROBELLI, C.; RABELLOTTI, R., (2005), Upgrading in global volume chains: Lessons 
from Latin American clusters, World Development, 33(4), 549-573.

HEJAZI, R.; GHANBARI, M.; ALIPOUR, M., (2016), Intellectual, human and structural capital effects on firm performance as measured by Tobin's $Q$, Knowledge and Process Management, 23(4), 259-273.

HSU, L.; WANG, C., (2010), Clarifying the effect of intellectual capital on performace: The mediating role of dynamic capability, British Journal of Management, 23(2), 179-205.

HSU, Y.; FANG, W., (2009), Intellectual capital and new product development performance: The mediating role of organizational learning capability, Technological Forecasting and Social Change, 76(5), 66-677.

IAZZOLINO, G.; LAISE, D.; MIGLIANO, G., (2014), Measuring value creation: VAIC and EVA, Measuring Business Excellence, 18(1), 8-21.

IFAC, (1998), Measurement and management of intellectual capital - An introduction, study no. 7, New York, NY: International Federation of Accountants.

IRAWANTI, S.; RACE, D.; STEWART, H.; PARLINAH, N.; SUKA, A., (2017), Understanding the timber value chain in community-based forestry in Indonesia: Analysis of sengon in central Java, Journal of Sustainable Forestry, 36(8), 847-862.

KAPLINSKY, R. (2000), Globalization and unequalization: What can be learned from value chain analysis? Journal of Development Studies, 37(2), 117-146.

KAVIDA, V.; SIVAKOUMAR, N., (2009), Intellectual capital: A strategic management perspective, The IUP Journal of Knowledge Management, 7, 55-69.

KAYA, F.; SAHIN, G.; GURSON, P., (2010), Intellectual capital in organizations, Problems and Perspectives in Management, 8(1), 153-160.

KOOTA, P.; TAKALA, J., (1998), Developing a performance measurement system for world-class distribution logistics by using activity-based costing and management: Case: Basic metal industries, International Journal of Technology Management, 16(1-3), 267-280.

KUCHARČIKOVÁ, A.; TOKARČIKOVÁ, E.; BLAŠKOVÁ, M., (2015), Human capital management - Aspect of human capital efficiency in university education, Procedia - Social and Behavioral Sciences, $177,48-60$.

LANDEKIĆ, M., ŠPORČIĆ, M., MARTINIĆ, I., \& BAKARIĆ, M. (2015). Influence of organizational culture on firm efficiency: competing values framework in Croatian forestry. Scandinavian Journal of Forest Research, 30(7), 624-636.

LEITNER, K., (2011), The effect of intellectual capital on product innovativeness in SMEs, International Journal of Technology Management, 53(1), 1-18.

LEV, B.; RADHAKRISHNAN, S.; EVANS, P., (2016), Organizational capital: A CEO's guide to measuring and managing enterprise intangibles, The Center for Global Enterprise.

LOPES, I.; MARTINS, M., (2006), The new business models in the knowledge economy: The strategic way to value creation, The Electronic Journal of Knowledge Management, 4(2), 159-168. 
LOUREIRO, M.; DORREGO, P., (2012), Intellectual capital and system of innovation: What really matters at innovative SMEs, Intangible Capital, 8(2), 239-274.

MAHARANI, T.; FUAD, K., (2020), The effect of human capital, structural capital, customer capital, managerial ownership, and leverage toward profitability of company, Journal of Advanced Multidisciplinary Research, 1(1), 46-62.

MAREY-PEREZ, M.; DIAZ-VARELA, E.; CALVO-GONZALEZ, A., (2014), Does higher owner participation increase conflicts over common land? An analysis of communal forests in Galicia (Spain), iForest - Biogeosciences and Forestry, 8, 533-543.

MARTíN-DE CASTRO, G. (2014). Intellectual capital and the firm: some remaining questions and prospects. Knowledge Management Research \& Practice, 12(3), 239-245.

MARTOS, M.; F-JARDÓN, C.; FIGUEROA, P., (2008), Evaluación y relaciones entre las dimensiones del capital intelectual: El caso de la cadena de la madera de Oberá (Argentina), Intangible Capital, $4(2), 67-101$.

MIDIANTARI, P.; AGUSTIA, D., (2020), Impact of intellectual capital on firm value through corporate reputation as a mediating variable, Journal of Security and Sustainable Issues, 9(4), 12031213.

MOON, Y.; KYM, H., (2006), A model for the value of intellectual capital, Canadian Journal of Administrative Sciences, 23(3), 525-528.

MOURÃO, P.; MARTINHO, V., (2016), Discussing structural breaks in the Portuguese regulation on forest fires - An economic approach, Land Use Policy, 54, 460-478.

NEJJARI, Z.; AAMOUM, H., (2020), Intellectual capital as a generator of innovation in companies: A systematic review, Humanities \& Social Sciences Reviews, 8(1), 464-479.

NIELSEN, H.; NIELSEN, C., (2019), Value creation in business models is based on intellectual capital and only intellectual capital!, Journal of Business Models, 7(2), 64-81.

PEDRO, E.; LEITÃO, J.; ALVES, H., (2018), Back to the future of intellectual capital research: A systematic literature review, Management Decision, 56(11), 2502-2583.

PIETROBELLI, C.; RABELLOTTI, R., (2014), Upgrading in clusters and value chains in Latin America: The role of policies, Sustainable Development Department Best Practices Series, Inter-American Development Bank, 1-106.

POSCHEN, P.; SIEVERS, M.; ABTEW, A., (2013), Creating rural employment and generating income in forest-based value chains, In: Pretzch, J.; Darr, D.; Uibrig, H.; Auch, E. (eds) Forests and Rural Development, Tropical Forestry, vol. 9, Springer,Berlin, Heidelberg.

PULIC, A. (2000). VAICTM an accounting tool for IC management, International Journal of Technology Management, 20(5/6/7/8), 702-714.

RAWAL, N.; MAHINI, S., (2014), Models and methods of intellectual capital accounting, Advances in Economics and Business Management, 1(1), 21-26.

ROOS, G.; ROOS. J., (1997), Measuring your company's intellectual performance, Long Range 
Planning, 30(3), 413-426.

ROOS, J., (1998), Exploring the concept of intellectual capital, Long Range Planning, 31(1), 150-153.

SAINT-ONGE, H., (1996), Tacit knowledge the key to the strategic alignment of intellectual capital, Strategy \& Leadership, 24(2), 10-16.

SARMENTO, E.; DORES, V., (2013), A fileira florestal no contexto da economia nacional: A produtividade e a especialização regional, Silva Lusitana, no. Especial, 21-37.

SAYER, J.; MAGINNIS, S., (2005) New challenges for forest management, in B.B., SAYER, J.; MAGINNIS, S.; LAURIE, M., (2005), (Ed.), Forests in landscapes: Ecosystem approaches to sustainability, The Earthscan Forestry Library, London, 1-16.

SCHIUMA, G.; LERRO, A., (2008), Intellectual capital and company's performance improvement, Measuring Business Excellence, 12(2), 3-9.

SCHMITZ, H. (1995). Collective efficiency: Growth path for small-scale industry. Journal of Development Studies, 31(4), 529-566.

SHERIF, M.; ELSAYED, M., (2016), The impact of intellectual capital on corporate performance: Evidence from the Egyptian insurance market, International Journal of Innovation Management, 20(3), 1650034.

SHIH, C.; CHEN, W.; MORRISON, M., (2010), The impact of intellectual capital on business performance in Taiwanese design industry, Journal of Knowledge Management Practice, 11(1),

SLEE, B., (2006), The socio-economic evaluation of the impact of forestry on rural development: A regional level analysis, Forest Policy and Economics, 8(5), 542-554.

STEWART, T., (1991), Brainpower, Fortune, 3, 44-56.

STEWART, T., (1994), "Your company's most valuable asset: Intellectual capital”, Fortune, 68-74.

STEWART, T., (1997), Intellectual capital: The new wealth of organizations, New York: Doubleday Publishing.

STEWART, T., (1998), Capital intelectual: A nova riqueza das organizações, Edições Sílabo, Lisbon, ISBN: 972-618-202-6.

SUDIBYI, Y.; SUTANTO, K., (2020), Environmental consciousness and corporate social responsibility as drivers of green intellectual capital, International Journal of Innovation, Creativity and Change, 13(4), 716-726.

SVEIBY, K., (1998), Intellectual capital: Thinking ahead, Australian CPA, June, 18-22.

TEISCHINGER, A., (2009), The forest-based sector value chain - A tentative survey, Lenzinger Berichte, 87, 1-10.

TSAI, W.; GHOSHAL, S., (1998), Social capital and value creation: The role of intrafirm networks, Academy of Management Journal, 41(4), 464-476.

UJWARY-GIL, A., (2014), Knowledge capital earnings of a company listed on Warsaw stock exchange, https://papers.ssrn.com/sol3/papers.cfm?abstract_id=2496957 
URBAN, B.; JOUBERT, G., (2017), Multidimensional and comparative study on intellectual capital and organizational performance, Journal of Business Economics \& Management, 18(1), 84-99.

URBANEK, G. (2016). The links between the Intellectual Capital Efficiency Ratio (ICER) and the performance of Polish listed companies from the food industry sector, Electronic Journal of Knowledge Management, 14(4), 220-230.

WU, S.; LIN, L., HSU, M., (2007), Intellectual capital, dynamic capabilities and innovative performance of organizations, International Journal of Technology Managmenent, 39(3-4), 279-296.

XU, J.; WANG, B., (2018), Intellectual capital, financial performance and companies' sustainable growth: Evidence from the Korean manufacturing industry, Sustainability, 10(12), 1-15.

YUSLIZA, M.; YONG, J.; TANVEER, M.; RAMAYAH, T.; FAEZAH, J.; MUHAMMAD, Z., (2020), A structural model of the impact of green intellectual capital on sustainable performance, Journal of Cleaner Production, 249, 119334.

ZYL, C., (2005), Structural capital management creates sustainable competitiveness and prolonged first-mover advantage - Intellectual capital management series - (article 3 of 3), Acta Commercii, 84-95. 


\section{AUTHORS}

\section{Carlos-Maria Fernandez Jardón}

Professor of Econometrics at the University of Vigo. PhD in Economics and Mathematics from the University of Navarre (Spain).

E-mail: cjardon@uvigo.es

ORCID: https://orcid.org/0000-0003-0888-2055

\section{Amandio F. C. da Silva}

Is a Visiting Faculty at the Instituto Superior de Contabilidade e Administração (ISCA) da Universidade de Aveiro, Portugal, in the Atlântico Business School.

E-mail: amandio_dasilva@yahoo.co.in

ORCID: https://orcid.org/0000-0002-1805-3691

Contribution of authors.

\begin{tabular}{|l|c|c|}
\hline \multicolumn{1}{|c|}{ Contribution } & [Author 1] & [Author 2] \\
\hline 1. Definition of research problem & $\mathrm{V}$ & \\
\hline 2. Development of hypotheses or research questions (empirical studies) & $\mathrm{V}$ & $\mathrm{V}$ \\
\hline 3. Development of theoretical propositions (theoretical work) & $\mathrm{V}$ & $\mathrm{V}$ \\
\hline 4. Theoretical foundation / Literature review & $\mathrm{V}$ & $\mathrm{V}$ \\
\hline 5. Definition of methodological procedures & $\mathrm{V}$ & \\
\hline 6. Data collection & & $\mathrm{V}$ \\
\hline 7. Statistical analysis & $\mathrm{V}$ & $\mathrm{V}$ \\
\hline 8. Analysis and interpretation of data & $\mathrm{V}$ & $\mathrm{V}$ \\
\hline 9. Critical revision of the manuscript & $\mathrm{V}$ & \\
\hline 10. Manuscript writing & $\mathrm{V}$ & \\
\hline 11. Other (please specify) & & $\mathrm{V}$ \\
\hline
\end{tabular}

